\title{
Commentary
}

\section{Engaged Science: Strategies, Opportunities and Benefits}

\author{
Adrienne B. Keller $1, *$ (i) and Vijay S. Limaye ${ }^{2, *}$ (i) \\ 1 Department of Ecology, Evolution, and Behavior, College of Biological Sciences, University of Minnesota, \\ St Paul, MN 55108, USA \\ 2 Natural Resources Defense Council, New York, NY 10011, USA \\ * Correspondence: kellerab@umn.edu (A.B.K.); vlimaye@nrdc.org (V.S.L.)
}

Received: 10 August 2020; Accepted: 16 September 2020; Published: 23 September 2020

check for updates

\begin{abstract}
Science is increasingly intertwined with an array of pressing societal issues, from the coronavirus pandemic response, to environmental concerns, to major national security threats. Meanwhile, scientists remain one of the most trusted groups of professionals and are looked to as both sources of inspiration for society's collective curiosity and effective messengers of useful technical information. While traditional scientific training has not emphasized the skills needed to coherently translate nuanced scientific research to audiences beyond one's inner academic circle, today's scientists (and, prominently, scientists-in-training) are increasingly seeking out ways to engage with such broader audiences and apply their skills to real-world problems. Here, we offer engagement strategies for scientists across levels of scale (e.g., at the individual, lab group, department/university, and cross-institutional levels), highlighting both existing opportunities and areas where improved capacity for science engagement is warranted. We argue that efforts to enhance and harmonize engagement efforts will have multi-faceted benefits, with greater opportunities for science-society dialogues, enhanced equity and inclusivity in such dialogues, and broader professional opportunities for early career scientists. While we acknowledge that the development of effective scientific engagement skills requires interest, effort, time and resources, we argue that the development of skills for effective public engagement is a worthwhile and necessary element of scientific training that enables unique, rewarding, and multifaceted professional opportunities.
\end{abstract}

Keywords: science advocacy; policy; science training; public engagement; science communication

\section{Introduction}

Urgent and transformative changes are necessary for society to avoid ecological and humanitarian devastation within the next century, according to several recent scientific reports, including the IPCC Special Report on Climate Change [1] and the United Nations Global Assessment Report on Biodiversity and Ecosystem Services [2]. There is broad scientific consensus on both the causes and potential consequences of climate change and biodiversity loss, and our arsenal of practical, science-informed solutions to address these threats is ever-expanding. However, society remains largely at an impasse, as major challenges exist in moving the political dial at all scales of government to achieve the necessary transformations. Central to this challenge of making science useful to inform such challenges is the tension between the systematic production of scientific models and knowledge, and the complex social systems in which such information is developed and acted upon [3]. Fundamentally, there continues to be a growing imbalance between our increasing understanding of the problems around us and the weak state of social and political forces to devise and implement equitable solutions to these problems.

The coronavirus pandemic has heightened the urgency of science-based policy responses [4], but unfortunately, widespread misconceptions that advocacy weakens scientific integrity and objectivity 
persist, and this problematic framing ultimately limits and often discourages scientists from willingly engaging in advocacy [5]. Much research has explored the potential drawbacks of scientists engaging in the advocacy space, with growing consensus that, in most cases, advocacy does not diminish the value of a scientist's work or reputation [6]. On the contrary, such engagement can complement and elevate scientific work by broadening professional networks, offering new perspectives by engaging with stakeholders and developing subject matter competencies outside one's discipline [7], and building broader social support and dedicated resources for the scientific enterprise $[8,9]$.

Our intent here is to move the discussion beyond if scientists should engage in advocacy to highlight how scientists (and especially scientists-in-training) can be effective agents of change and operate strategically within existing frameworks for engagement. The challenge is twofold: the perception that scientists cannot or should not engage with politically charged topics must be challenged, and existing models for effective scientific engagement must be expanded widely and rapidly $[10,11]$. Scientists are subject matter experts who are trusted messengers with critical thinking skills and familiarity with the intricacies of complicated issues [12]. Too often, these skills are confined to limited applications, and dialogue does not extend beyond the scientific community. Given their status as trained experts, scientists can and should play an integral role in driving necessary transformative policy change by serving as technically trained voices to inform society. Despite perceived partisan influence and expectations about the ramifications of public advocacy, public trust in science remains high $[6,13,14]$. While the need for scientific voices to inform public debates is not a new phenomenon, the training opportunities available for scientists are expanding-as is a broader recognition that scientists trained in effective public engagement skills are more effective leaders in their fields.

Just as effectively addressing climate change will require multifaceted solutions ranging from individual actions to regional and national policies to international trade agreements, meaningful science advocacy must also span all levels of scale and add value to existing advocacy strategies. Here, we consider opportunities for scientists to engage in advocacy across such levels, highlighting both existing opportunities and areas where improved capacity for science advocacy is warranted. We fully acknowledge that effective advocacy requires both skill and resources. However, rather than this requirement being a deterrent to scientists engaging in advocacy work, we argue that engagement in science advocacy is an activity aligned with the work that scientists are already being trained to do, and can offer unique and rewarding professional development opportunities. Moreover, engagement in science advocacy can enhance and broaden a scientist's toolkit and need not be viewed as a zero-sum game that takes away time and resources from one's research. For example, consider that practicing science advocacy can offer new challenges in communicating and translating scientific research and can foster new perspectives on research questions by engaging with novel audiences.

While traditional scientific training has generally not emphasized the skills needed to coherently translate nuanced scientific research to audiences beyond one's inner academic circle, today's scientists (and, prominently, scientists-in-training) are increasingly seeking out ways to engage with such broader audiences in an integrated way and apply their skills to real-world problems through novel channels $[10,15]$. To this end, a more holistic and strategic approach to training today's scientists is urgently needed, with course offerings and other learning opportunities becoming the standard of effective graduate student scientific training.

Below, we discuss engagement strategies and opportunities for scientists across levels of scale (e.g., at the individual, lab group, department/university, and cross-institutional levels), highlighting both existing opportunities and areas where improved capacity for science engagement is warranted. We argue that efforts to enhance and harmonize existing efforts would have multi-faceted benefits, with greater opportunities for science society dialogues, enhanced equity and inclusivity in such dialogues, and broader professional opportunities for early career scientists. This effort stems from our personal experiences as trainees in a 2018 cross-institutional science engagement program of training facilitated by COMPASS and the Union of Concerned Scientists $[15,16]$. The training program provided a group 
of graduate students and early career scientists with actionable paths for scientific engagement, which we describe in further detail in this commentary.

\section{Strategies for Engagement}

Scientists and scientists-in-training can seek out opportunities for engagement through many venues. In this section, we identify opportunities at different levels; importantly, these do not represent a defined hierarchy or proposed sequence. Rather, this structure demonstrates multiple entry points into science engagement, depending on one's interests, career stage, scientific area of expertise and available resources. Evidence indicates that the degree to which values are shared between scientists and their audiences influences the degree of risk for engaging as a science advocate with that audience [16]. To demonstrate, Figure 1 exemplifies how the interests of scientists and non-scientists may intersect and complement one another. First, both constituencies are broadly interested in improving overall public understanding of the scientific process and the inclusivity of that process. Second, these groups aim to improve the relevance of science to society through the consideration of new perspectives, values, goals, and creative methodological approaches [17]. Importantly, this type of interactive science engagement can enhance the capacity for public engagement by both scientists and other stakeholders. In this way, engagement is critical not only as a means to informing policy, but as an end in itself to democratizing science and centering people in environmental issues $[10,18]$.

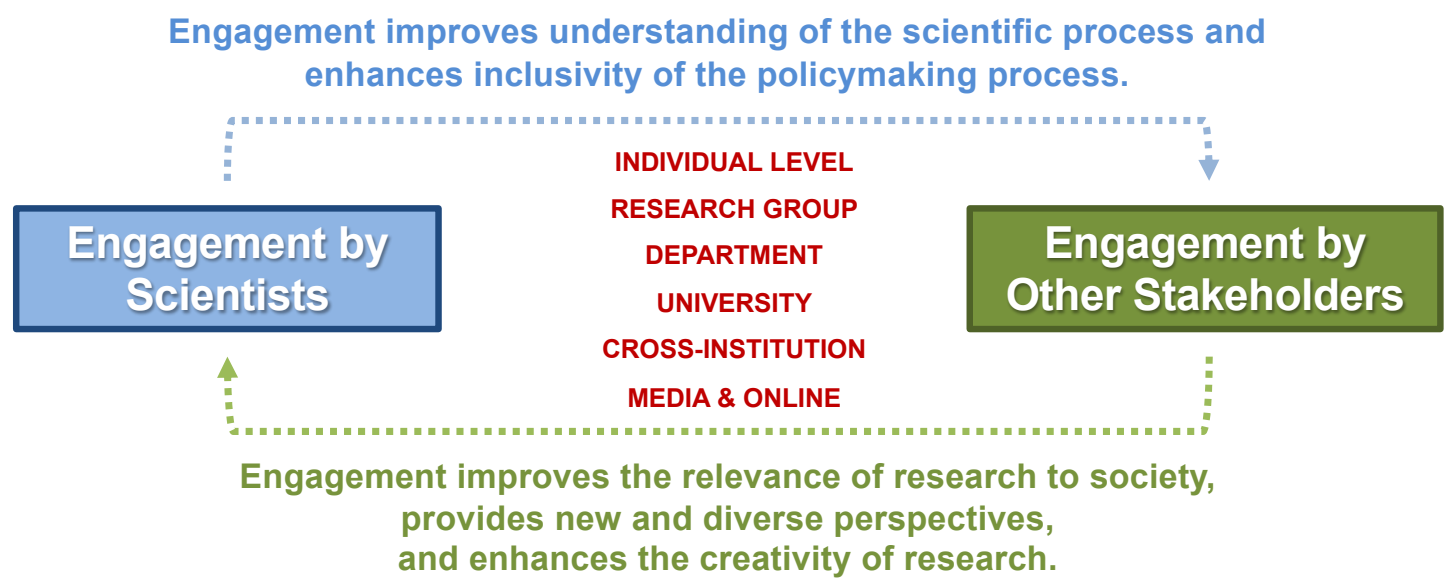

Figure 1. Shared values between engaged scientists and other stakeholders can foster stronger outcomes. Scientists can engage with other stakeholders at multiple levels in order to advance the application of research for societal benefit.

In identifying opportunities at different levels, in the next sections, we highlight and provide examples of tangible actions that can be undertaken. We also highlight gaps where few examples exist, and emphasize the existing barriers that may prevent trainees and early career scientists from engaging in science advocacy (e.g., limitations in funding, time, mentorship opportunities, or formal training-especially when any skill development has to be accomplished in addition to other course requirements [19]). We also emphasize the benefits of these engagement opportunities, including the demonstration of broader impacts, linkages to professional networks, broadened reach of research findings, expansion of professional opportunities, and access to new funding sources. Notably, individual-level science engagement efforts may also lead to new opportunities for collaborative efforts, and vice versa. Because these strategies serve multiple goals that are both directly measurable and less defined, objectively assessing their degree of "success" can be challenging [20]. A reflective approach to applied environmental research over time can help to identify and refine strategies and approaches tailored to specific contexts. 


\subsection{Individual Level}

For many scientists, simple, discrete, and individual actions can be the most feasible entry point into science advocacy work. This may be especially true for early career scientists who often have narrow professional networks and limited agency to stimulate institutional change. While it may feel like a big leap to move from the field or benchtop to the advocacy arena, the skills required for advocacy work overlap significantly with traditional scientific training.

Taking action as an individual allows for flexibility in choosing activities that fit within one's schedule and resonate with particular interests and skill sets. Individuals can play a powerful role in emphasizing the importance of scientific integrity and evidence-based decision making, something that can be easily lost in the 24-h news cycle. Furthermore, individuals can be effective agents of change through small, consistent actions that harness communication skills: talking about issues with non-experts, placing calls to legislators, writing letters to newspaper editors about scientific topics in the news, thanking Congressional representatives for federal funding, and participating in Capitol Hill days with scientific societies [8]. Furthermore, individuals can volunteer to serve in scientific society outreach positions to broaden their understanding of the science policy interface.

More substantial efforts could include writing op-eds [21,22] and letters to newspaper editors [23], which allow for more narrative explication and storytelling and making arguments for policy action based on both qualitative and quantitative evidence. In drafting these materials, trainees and established researchers can rely on key science communication skills to effectively bridge the divide from research into effective engagement [24]. Beyond writing for print media, individual scientists can also organize local science outreach "café discussions" that focus on timely research topics [25]. Where public policy issues intersect with one's training area, individuals and groups can craft written and oral public comments related to current local, state, and federal government proposals [26,27]. Participation in these public comment activities is not a skill traditionally developed in graduate training, yet it provides a concrete platform from which scientists-in-training can develop and refine arguments and gain experience in translating technical arguments to policymakers [28].

We also encourage trainees to consider scientific conferences as opportunities to engage in the science advocacy policy interface. Participating in relevant sessions at larger conferences can give a taste for advocacy work (e.g., American Geophysical Union's Fall Meeting), while more targeted conferences typically offer greater opportunities to engage with and develop meaningful relationships with policy makers (e.g., state and federal government agency association conferences, such as the Northeast Fish and Wildlife Conference). Scientists can actively seek out such conferences using resources such as the International Network for Government Science Advice [29]. With the wealth of communication tools and opportunities available today, individual action can easily blend into collective action (see next sections).

\subsection{Research Group Level}

Research or lab groups offer a low-risk, low-investment opportunity for organizing collective action among individual advocates and a platform for informal science advocacy professional development trainings. Many lab groups meet regularly, and we have anecdotally observed an increased interest in including professional development in science engagement skills as a part of such meetings. Therefore, we suggest that lab group meetings can be an effective arena for both science advocacy training and action related to a given research group's area of expertise. For example, lab groups might dedicate one meeting to collectively write an evidence-based public comment or a lay summary of their research for policymakers, or a commentary article summarizing and communicating the salience of recent scientific advances or proposed policies that relate to current social challenges [30-33]. Moreover, intentionally planning research group meetings to emphasize the importance of science engagement and advocacy as a component (rather than outside of) holistic research skill development can stimulate a shift in cultural thinking about the value of advocacy in academic arenas, as well as provide tangible training for scientists at all stages of their careers. For example, when providing feedback on grant 
proposals, research team members may provide feedback on the broader impacts as well as the research proposal components of the grant.

Research groups can also proactively and collaboratively learn about public policies related to their areas of expertise, and the history of how such policies have been applied [34]. Such work, while time-intensive, can ultimately allow communities and groups of researchers to develop proposals that are more sensitive to historical gender, racial, and socioeconomic biases in scientific research funding and execution, and better prepare trainees for active engagement in a more inclusive and equitable research process. In a similar way, improved understanding of funding opportunities and budgets at multiple scales (e.g., university, state, federal, and international) allows researchers to target their advocacy efforts during budget discussions amongst policy-makers [8]. Science advocacy on topics such as budgets can take time to achieve results, but the establishment of working relationships with stakeholders allows for trust to grow over time [35].

\subsection{Department Level}

University departments can encourage the professional development of engaged scientists by explicitly acknowledging both that science advocacy skills are important to many students' future careers and that pressing societal challenges require scientists who are willing to directly engage with public policy. Academic department leadership can lead by example (by engaging in strategies identified in Section 2.1, for example) and secure funding for students to attend advocacy workshops, conferences that emphasize public engagement, and media communication training. These settings are also ideal places to draw attention to the importance of engaged science by providing awards for students excelling in advocacy efforts.

\subsection{University Level}

Experts largely agree that higher education institutions have a social contract to "facilitate dialogue and collaboration with other sections of society", as a means to advancing societal goals [36]. Faculty, students, and staff should be empowered and enabled by university leadership to coordinate efforts to provide adequate resources and opportunities for engagement of the university community in helping to address real-world problems [37]. Excellent examples of both "bottom-up" graduate-student driven programs (e.g., Engage, founded at the University of Washington; Public Communication for Researchers, founded at Carnegie Mellon University; and Scientists with Stories, founded at Duke University and University of North Carolina Chapel Hill) and "top-down" University programs (e.g., the Center for Communicating Science at Stony Brook University) exist [38]. However, such programs should become common place within higher education, be inclusive and well-supported and advertised by universities, and focus on changing the culture of separation between knowledge generation and public engagement [15].

Such engagement opportunities are critical and strategic components of graduate training, and complementary to traditional research training [39]. During graduate training, students can take advantage of coursework and skill development that will help them to achieve success in an array of career trajectories. Courses in policy analysis can help to acquaint students with the wider context in which their technical expertise exists, and can illuminate avenues for achieving political change through the scientific enterprise. These settings can also identify barriers that policymakers face in applying scientific findings to address societal challenges [40,41] and potential strategies to overcome such obstacles.

Communication skills training is widely applicable to science advocacy work. The graduate school learning environment offers students a chance to practice synthesizing their research and translating it to other audiences (including undergraduate students through teaching, graduate student colleagues, other experts within a specific field, and members of the public). Such work translates to science advocacy, as both require explaining compelling problems through a balanced approach that is both technically sound and approachable. Universities are also ideal settings for 
scientists-in-training to form and maintain student science advocacy groups [42]. Beyond existing opportunities, universities could also marshal resources to develop science advocacy centers that serve as campus hubs for the training and enrichment of scientists seeking public engagement opportunities, modeled after teaching and learning centers that are now common across universities. Such science advocacy centers could facilitate trainings and help students identify targeted resources based on their interests. Some graduate school professional development programs already offer relevant workshops on this type of professionalization. Additionally, many universities that receive research funding already staff government relations offices, and an advocacy center could invite those staffers to interact with scientists-in-training, while providing more information about the nature of government relations advocacy.

\subsection{Cross-Institution}

Looking beyond the campus, there are a growing number of cross-institutional opportunities for scientists-in-training to enhance their professional development for engaged science. For example, several non-profit organizations provide fellowships that offer early career scientists venues to practice scientific advocacy and science communication skills [34,43-46].

Furthermore, professional scientific societies are natural places for graduate trainees to seek out more experience with science policy and advocacy opportunities and broaden their networks to learn from both trainee colleagues and more established experts in the field, some of whom have been engaging in advocacy for years. Some of these groups encourage the member-led development of position [47] and policy statements [48]; collaboration on such efforts can help to facilitate connections between students and early career scientists with more experienced members, serve an internal organizing and deliberation function, and support external advocacy efforts. Written letters from professional societies can hold more influence than those from individual scientists not connected to a larger, established scientific enterprise [35]. Students can also help to translate these statements into fact sheets and other useful information for non-expert audiences. Beyond one's particular scientific society and niche disciplinary interests, other platforms, such as the Union of Concerned Scientists' team-based initiative [49] and the National Science Policy Network [50], enable trainees to engage with grassroots initiatives while tapping into a broader network of established advocates, reducing the likelihood of duplicative engagement and enabling the more strategic deployment of limited time and financial resources [51].

\subsection{Media and Online Engagement}

\subsubsection{Media}

This may come as a surprise, but most journalists are eager to hear from scientists, especially at local news sources. Over time, as a scientist's relationship and trust matures with a journalist, scientists become a valuable and accessible resource of technical expertise and context. In return, members of the press (who are practiced storytellers with a knack for accessible communication methods) can help to disseminate one's scientific message to a wide audience. Journalists are trained to focus on eliciting the main points out of trusted technical experts, such as the novelty and implications of new research, and framing the work within larger story narratives, which are the center-piece of effective science advocacy [52]. Organizations such as SciLine, which help to curate researcher listings for journalists to reach out to on specific topics, can help to facilitate effective working relationships between subject matter experts and members of the press and also diversify scientific voices represented in the media [53].

\subsubsection{Online}

Scientists may consider broadening the reach of their work and ideas by communicating through diverse and creative channels that extend beyond the peer-reviewed literature. Online tools 
(e.g., webinars, social media such as Twitter and Instagram, blog posts [54-57], videos [58-60], and audio podcasts [61]) enable more direct communication to members of the public and are often free to use. These online communication modes offer opportunities to shed light on different aspects of one's work in a conversational tone and provide more flexibility to contextualize results; in doing so, this avenue for research dissemination may even provide new insights to bring back to the lab bench, field site, or modeling domain [62]. In the context of the COVID-19 pandemic and its curtailment of travel, well-designed online workshops and conferences [63,64] can facilitate exchange amongst international participants and enable new communities to participate in scientific engagement and outreach.

Twitter, in particular, is a dynamic platform that allows for direct engagement amongst scientists and between scientists and particular "targeted" populations, such as journalists, policymakers, educators, parents, youth, scientists-in-training, and international audiences. The low barriers to entry on such online sites can be thought of as "shortcuts" to action that allow trainees and early career scientists to participate in online dialogues and counter professional isolation without the traditional obstacles to access. In this way, tools like Twitter can help to elevate minority voices, but only through active efforts to engage with such voices and facilitate inclusive discussions $[65,66]$. However, just tweeting about the need for evidence-based decision-making in public policy is not sufficient; digital tools should not be a substitute for real-world skill development and advocacy but rather complement those efforts. For those who are unfamiliar or uncomfortable with (at times hostile) online gathering spaces like Twitter, we suggest taking time to pilot the use of such platforms and evaluate what, if any, benefits can be derived from varying levels of participation (ranging from no participation at all, to passive consumption of content, to active contributions, to online dialogues).

\section{Conclusions}

The engagement opportunities presented here offer mutual benefits to individual scientists, community groups and society at-large. Science communication practice is vital to scientists at all career stages, especially "translation" skills that enable technical experts to participate in useful dialogues with the lay public, policymakers, and the media. In the same way, advocacy work that requires collating various lines of evidence, and providing evidence-based policy recommendations parallels the skills needed for synthesizing scientific literature. These translation skills are not confined to the written word: data analysis and visualization skills are essential for appropriately interpreting and bringing scientific evidence to life.

While the need for sound public policy based on scientific evidence has never been greater, there remain important structural and perceived obstacles that inhibit the full and effective participation of scientists in public policy decisions. Our overview of science engagement opportunities, barriers, and benefits draws attention to myriad actions scientists at all career stages can take to improve the reach and utility of their work and to better integrate themselves into advocacy channels. Our message to scientists, in particular, is that skill development in public engagement and advocacy largely complements, rather than conflicts with, the objectives of traditional scientific training efforts.

Author Contributions: Conceptualization, A.B.K. and V.S.L.; methodology, A.B.K. and V.S.L.; formal analysis, A.B.K. and V.S.L.; investigation, A.B.K. and V.S.L.; resources, A.B.K. and V.S.L.; writing-Original draft preparation, A.B.K. and V.S.L.; writing-Review and editing, A.B.K. and V.S.L.; visualization, A.B.K. and V.S.L. All authors have read and agreed to the published version of the manuscript.

Funding: This research received no external funding.

Acknowledgments: We thank COMPASS and the Union of Concerned Scientists (UCS) for their training, community building, and financial support that sparked the genesis of this project. We thank the entirety of our COMPASS Science Sentinels and UCS Science and Democracy Fellows cohort, who provided energy, inspiration and diverse perspectives to this work. We particularly thank Amanda Fencl, Nick Santos, Amanda Stanley, and Mohamed Yakub for their detailed and thoughtful feedback on this work.

Conflicts of Interest: The authors declare no conflict of interest. 


\section{References}

1. Allen, M.; Antwi-Agyei, P.; Aragon-Durand, F.; Babiker, M.; Bertoldi, P.; Bind, M.; Brown, S.; Buckeridge, M.; Camilloni, I.; Cartwright, A. Technical Summary: Global Warming of $1.5^{\circ} \mathrm{C}$. An IPCC Special Report on the Impacts of Global Warming of $1.5^{\circ} \mathrm{C}$ Above Pre-Industrial Levels and Related Global Greenhouse Gas Emission Pathways, in the Context of Strengthening the Global Response to the Threat of Climate Change, Sustainable Development, and Efforts to Eradicate Poverty; Intergovernmental Panel on Climate Change: Geneva, Switzerland, 2019.

2. Díaz, S.; Settele, J.; Brondízio, E.; Ngo, H.; Guèze, M.; Agard, J.; Arneth, A.; Balvanera, P.; Brauman, K.; Butchart, S. Summary for Policymakers of the Global Assessment Report on Biodiversity and Ecosystem Services of the Intergovernmental Science-Policy Platform on Biodiversity and Ecosystem Services; Intergovernmental Science-Policy Platform on Biodiversity and Ecosystem Services: Bonn, Germany, 2019.

3. Jasanoff, S. A new climate for society. Theory Cult. Soc. 2010, 27, 233-253. [CrossRef]

4. United Nations Department of Economic and Social Affairs. COVID-19 Response Demands Better Use of Science and Technology; United Nations Department of Economic and Social Affairs: New York, NY, USA, 2020.

5. Garrard, G.E.; Fidler, F.; Wintle, B.C.; Chee, Y.E.; Bekessy, S.A. Beyond advocacy: Making space for conservation scientists in public debate. Conserv. Lett. 2015, 9, 208-212. [CrossRef]

6. Kotcher, J.; Myers, T.; Vraga, E.K.; Stenhouse, N.; Maibach, E.W. Does engagement in advocacy hurt the credibility of scientists? Results from a randomized national survey experiment. Environ. Commun. 2017, 11, 415-429. [CrossRef]

7. Mitchell, C.L.; Graham, A. Evidence-based advocacy for municipal climate change action. J. Plan. Educ. Res. 2017, 40, 31-43. [CrossRef]

8. Godlee, F. Research is the future: Get involved. BMJ 2015, 351, 2. [CrossRef]

9. Zumba, J. Science advocacy and politics. CSA News 2017, 62, 18. [CrossRef]

10. Keeler, B.L.; Chaplin, R.E.; Guerry, A.D.; Addison, P.F.E.; Bettigole, C.; Burke, I.C.; Gentry, B.; Chambliss, L.; Young, C.; Travis, A.J.; et al. Society is ready for a new kind of science-Is academia? BioScience 2017, 67, 591-592. [CrossRef]

11. Limaye, V.; Keller, A. Engaged Science: 6 Tips for the Trump Era (NRDC Blog). Available online: https: //www.nrdc.org/experts/vijay-limaye/engaged-science-6-tips-trump-era (accessed on 11 October 2019).

12. Baron, N. Escape from the Ivory Tower; Island Press: Washington, DC, USA, 2010.

13. Donner, S.D. Risk and responsibility in public engagement by climate scientists: Reconsidering advocacy during the Trump era. Environ. Commun. 2017, 11, 1-4. [CrossRef]

14. Nisbet, M. The march for Science: Partisan protests put public trust in scientists at risk. Quality 2017, 41, 18-20.

15. Smith, B.; Baron, N.; English, C.; Galindo, H.; Goldman, E.; McLeod, K.; Miner, M.; Neeley, E. COMPASS: Navigating the rules of scientific engagement. PLoS Biol. 2013, 11, e1001552. [CrossRef]

16. Schmidt, G.; Donner, S.D. Scientific advocacy: A tool for assessing the risks of engagement. Bull. At. Sci. 2017, 73, 344-347. [CrossRef] [PubMed]

17. Nisbet, M.C.; Scheufele, D.A. What's next for science communication? Promising directions and lingering distractions. Am. J. Bot. 2009, 96, 1767-1778. [CrossRef] [PubMed]

18. Selin, C.; Rawlings, K.C.; De Ridder-Vignone, K.; Sadowski, J.; Allende, C.A.; Gano, G.; Davies, S.R.; Guston, D.H. Experiments in engagement: Designing public engagement with science and technology for capacity building. Public Underst. Sci. 2016, 26, 634-649. [CrossRef] [PubMed]

19. Leshner, A.I. Outreach training needed. Science 2007, 315, 161. [CrossRef]

20. Cooke, S.J.; Rytwinski, T.; Taylor, J.J.; Nyboer, E.A.; Nguyen, V.M.; Bennett, J.R.; Young, N.; Aitken, S.; Auld, G.; Lane, J.-F.; et al. On success in applied environmental research-What is it, how can it be achieved, and how does one know when it has been achieved? Environ. Rev. 2020. [CrossRef]

21. Piontek, E.; Owen, J. Guest Commentary: Wind Energy Could Be a Boost for Boone County. Columbia Missourian. Available online: https://www.columbiamissourian.com/opinion/guest_commentaries/ guest-commentary-wind-energy-could-be-a-boost-for-boone-county/article_9b1b4448-83e8-11ea-921ceb4c7f5a3eae.html (accessed on 14 September 2020).

22. Berglund, E.; Wancour, L.; Hedayat-Zadeh, K. Montana Must Stand Up for Equality. Missoulian. Available online: https://missoulian.com/opinion/columnists/montana-must-stand-up-for-equality/article_df60b8baaeb7-5daf-870a-27e355274f58.html (accessed on 14 September 2020). 
23. Limaye, V.S. Air Pollution Standards (Letter to Editor). Available online: https://www.nytimes.com/2019/04/ 23/opinion/letters/air-pollution-environmental-protection-agency.html (accessed on 12 May 2020).

24. Aurbach, E.L.; Prater, K.E.; Cloyd, E.T.; Lindenfeld, L. Foundational Skills for Science Communication: A Preliminary Framework; Office of Academic Innovation, University of Michigan: Ann Arbor, MI, USA, 2019.

25. Downtown Lincon Association. Science Café-Climate Change. Available online: https://downtownlincoln. org/do/science-cafe-climate-change (accessed on 12 September 2020).

26. Walsh, R.; Ward, A. Public Comment Submitted to Regulations.gov Rulemaking Docket for U.S. Environmental Protection Agency Revised Definition of Waters of the United States (EPA-HQ-OW-2018-0149-5296). Available online: https://beta.regulations.gov/comment/EPA-HQ-OW-2018-0149--5296 (accessed on 14 September 2020).

27. Limaye, V.S. Oral Statement from Vijay Limaye, Natural Resources Defense Council to EPA Clean Air Scientific Advisory Committee (CASAC) on EPA Draft Ozone Integrated Science Assessment and Policy Assessment. Available online: https://yosemite.epa.gov/sab/sabproduct.nsf/2ECE012FCACB055A852585120055C4B7/ \$File/2020-02-11_limaye_comments_at_casac_03_isa_pa.pdf (accessed on 15 September 2020).

28. Union of Concerned Scientists Engaging with Policymakers. Available online: https://www.ucsusa.org/takeaction/science-network/engaging-policymakers (accessed on 11 October 2019).

29. International Network for Government Science Advice (INGSA). Available online: https://www.ingsa.org/ (accessed on 10 September 2020).

30. Limaye, V.S.; Knowlton, K. Shining new light on long-term ozone harms. JAMA Intern. Med. 2020, $180,115$. [CrossRef]

31. Patz, J.; Stull, V.J.; Limaye, V.S. A low-carbon future could improve global health and achieve economic benefits. JAMA 2020, 323, 1247. [CrossRef]

32. Goldman, G.T.; Dominici, F. Don't abandon evidence and process on air pollution policy. Science 2019, 363, 1398-1400. [CrossRef]

33. Peltier, R.E.; Goldman, G.T. It's not about transparency: Politics is intruding into USEPA science and it could cost the public's health. J. Expo. Sci. Environ. Epidemiol. 2020, 30, 594-595. [CrossRef]

34. Carney, J.P. Science advocacy, defined. Science 2014, 345, 243. [CrossRef]

35. Rosen, J. How Your Science Can Shape Policy. 2018. Available online: https://sciencejulia.wordpress.com/ 2018/10/18/how-your-science-can-shape-policy/ (accessed on 2 September 2020).

36. Lobera, J.; Secretariat, G. Delphi poll-Higher education for human and social development. In Higher Education in the World 3; Palgrave Macmillan: London, UK, 2008; pp. 307-331. ISBN 978-0-230-00048-3.

37. Tilbury, P.D. Higher education for sustainability: A global overview of commitment and progress. High. Educ. World 2011, 4, 18-28.

38. COMPASS Science Communication. GradSciComm: Mapping the Pathways to Integrate Science Communication Training into STEM Graduate Education. 2014. Available online: https: //www.compassscicomm.org/wp-content/uploads/2020/06/GradSciComm-Report-and-Recommendations.pdf (accessed on 2 September 2020).

39. Crone, W.C.; Dunwoody, S.L.; Rediske, R.K.; Ackerman, S.; Petersen, G.M.Z.; Yaros, R.A. Informal science education: A practicum for graduate students. Altern. High. Educ. 2011, 36, 291-304. [CrossRef]

40. Groffman, P.M.; Stylinski, C.; Nisbet, M.C.; Duarte, C.M.; Jordan, R.; Burgin, A.; Previtali, M.A.; Coloso, J. Restarting the conversation: Challenges at the interface between ecology and society. Front. Ecol. Environ. 2010, 8, 284-291. [CrossRef]

41. Fisher, J.R.B.; Wood, S.A.; Bradford, M.A.; Kelsey, T.R. Improving scientific impact: How to practice science that influences environmental policy and management. Conserv. Sci. Pr. 2020, 2, e210. [CrossRef]

42. Ruppersburg, C.C.; York, A.L. A beginner's guide to getting involved in science advocacy. Mol. Biol. Cell 2016, 27, 1181-1184. [CrossRef]

43. COMPASS Science Communication. Meet the Scientist Sentinels. Available online: https://www. compassscicomm.org/post/meet-the-scientist-sentinels (accessed on 11 October 2019).

44. Union of Concerned Scientists. The Science and Democracy Fellowship. Available online: https://www. ucsusa.org/take-action/science-network/science-and-democracy-fellowship (accessed on 11 October 2019). 
45. American Association for the Advancement of Science. Science \& Technology Policy Fellowships. Available online: https://www.aaas.org/programs/science-technology-policy-fellowships (accessed on 11 October 2019).

46. American Geophysical Union, AGU. Voices for Science. Available online: https://www.agu.org/Share-andAdvocate/Share/Sharing-science-network/Voices-for-science (accessed on 11 October 2019).

47. American Geophysical Union, AGU. Position Statement on Climate Change. Available online: https: //www.agu.org/Share-and-Advocate/Share/Policymakers/Position-Statements/Position_Climate (accessed on 12 September 2020).

48. American Public Health Association. Addressing Environmental Justice to Achieve Health Equity (Policy Statement). Available online: https://www.apha.org/policies-and-advocacy/public-health-policystatements/policy-database/2020/01/14/addressing-environmental-justice-to-achieve-health-equity (accessed on 12 September 2020).

49. Union of Concerned Scientists. Science Network Leaders. Available online: https://www.ucsusa.org/ resources/science-network-leaders (accessed on 12 September 2020).

50. National Science Policy Network. National Science Policy Network. Available online: https://scipolnetwork. org/ (accessed on 12 September 2020).

51. National Science Policy Network. Connecting Early Career Science Policy Advocates. Available online: http://scipolnetwork.org/ (accessed on 11 October 2019).

52. Irion, R. Science communication: A career where PhDs can make a difference. Mol. Boil. Cell 2015, 26, 591-593. [CrossRef] [PubMed]

53. American Association for the Advancement of Science. SciLine. Available online: https://www.sciline.org (accessed on 8 September 2020).

54. Keller, A. How failure fuels science: Perspectives from Two Early-Career Ecologists. SciU Blog. Available online: https://blogs.iu.edu/sciu/2019/09/28/how-failure-fuels-science/ (accessed on 12 September 2020).

55. Limaye, V.S.; Knowlton, K. Climate Change Is a Public Health Emergency. Inaction Is Costing Us. NRDC Blog. Available online: https://www.nrdc.org/experts/vijay-limaye/climate-change-public-health-emergencyinaction-costing-us (accessed on 10 September 2020).

56. Dobbin, K.; Fencl, A. Who governs California's drinking Water Systems? California WaterBlog. Available online: https://californiawaterblog.com/2019/09/01/who-governs-californias-drinking-watersystems/ (accessed on 10 September 2020).

57. Fencl, A.; Pauloo, R.; Escriva-Bou, A.; Guillon, H. Eastern San Joaquin Valley and Other CA Drinking Water Supplies at Risk in the Next Drought. California WaterBlog. Available online: https://californiawaterblog.com/2018/11/12/domestic-well-vulnerability-to-drought-in-californiascentral-valley/ (accessed on 10 September 2020).

58. Limaye, V.S. July Was Hottest on Record-And Dangerous Heat Hits Home. Available online: https: //www.nrdc.org/experts/vijay-limaye/july-was-hottest-record-and-dangerous-heat-hits-home (accessed on 12 August 2020).

59. Limaye, V.S. The Public Health Cost of Climate Change Is Already in the Billions. Available online: https: //www.nrdc.org/stories/public-health-cost-climate-change-already-billions (accessed on 12 September 2020).

60. 1000 STEM Women Project. Available online: https://1000stemwomen.wixsite.com/home (accessed on 12 September 2020).

61. Gill, J.; Laungani, R. Warm Regards (Podcast). Available online: https://warmregardspodcast.com/ (accessed on 2 September 2020).

62. American Geophysical Union. Share and Advocate for Science. Available online: https://www.agu.org/ Share-and-Advocate/Share (accessed on 11 October 2019).

63. National Association of Black Geoscientists 39th Annual Technical Conference. Available online: http: //www.nabg-us.org/conference-page.html (accessed on 12 September 2020).

64. SciComm. SciComm-A Science Communication Conference. Available online: http://www.scicommcon.org/ (accessed on 12 September 2020). 
65. Van Alstyne, M.; Brynjolfsson, E. Global Village or cyber-balkans? Modeling and measuring the integration of electronic communities. Manag. Sci. 2005, 51, 851-868. [CrossRef]

66. Shore, J.; Baek, J.; Dellarocas, C. Network Structure and Patterns of Information Diversity on Twitter. Boston University Questrom School of Business Research Paper 2016. Available online: https://ssrn.com/abstract= 2813342 (accessed on 2 September 2020).

(c)

(C) 2020 by the authors. Licensee MDPI, Basel, Switzerland. This article is an open access article distributed under the terms and conditions of the Creative Commons Attribution (CC BY) license (http://creativecommons.org/licenses/by/4.0/). 